\title{
Tryptophan Biosynthesis in Coprinus lagopus: A Genetic Analysis of Mutants
}

\author{
By M. J. TILBY \\ Department of Plant Biology and Microbiology, Queen Mary College, \\ University of London, London $E_{\mathrm{I}} 4 N S$
}

(Received I3 August 1975; revised 17 September 1975)

\begin{abstract}
SUMMARY
Thirty-one tryptophan-requiring mutants of Coprinus lagopus have been assigned by genetic and complementation analyses to four loci designated trp-I, $t r p-2, t r p-3$ and $t r p-4$. The $t r p-I$ and $t r p-3$ loci were located in group III and $t r p-2$ in group $\mathrm{G}$ of the linkage map. The trp-4 locus showed no linkage to the other $t r p$ loci or to markers in three additional linkage groups tested. From auxanographic tests and a study of accumulated biosynthetic intermediates, the enzymes controlled by each locus have been provisionally assigned. The $\operatorname{trp}-2$ and $\operatorname{trp}-3$ loci both appear necessary for anthranilate synthetase activity since mutants accumulated no intermediates. Only the trp- 3 mutant could utilize anthranilic acid, therefore the trp-2 locus must also be involved in a subsequent step in the pathway. The trp-4 mutants utilized indole and accumulated anthranilic acid, and hence this locus is involved in the conversion of anthranilic acid to indoleglycerol phosphate. The trp-I mutants utilized only tryptophan and accumulated indoleglycerol phosphate and anthranilic acid. They are therefore blocked in the final steps of the pathway catalysed by tryptophan synthetase.
\end{abstract}

\section{INTRODUCTION}

Studies of tryptophan biosynthesis in diverse micro-organisms and higher plants have revealed a common basic reaction sequence catalysed by a wide variety of enzyme structures (Fig. 1; see also Crawford, 1975). In bacteria, the number of genetic loci involved in specifying the necessary enzymes ranges from seven in Bacillus subtilis to five in Escherichia coli (Crawford, 1975). In fungi, there are five in Saccharomyces cerevisiae (Bonner, DeMoss \& Mills, I965) and four in Neurospora crassa (DeMoss, Jackson \& Chalmers, I967), Aspergillus nidulans (Roberts, 1967) and Coprinus radiatus (Henke, Guerdoux \& Hutter, 1973). In bacteria the loci are located in various types of clusters, generally forming operons, whereas, in fungi they are not clustered.

This report describes for the first time tryptophan-requiring mutants of Coprinus lagopus. The work is primarily a genetic study designed to provide a foundation for subsequent studies on the action of analogues of tryptophan. An indication as to the enzymic steps affected in the mutants is derived from auxanographic tests and by identification of accumulated intermediates. This allows some comparison of the enzymes in C. lagopus with those in other fungi. 


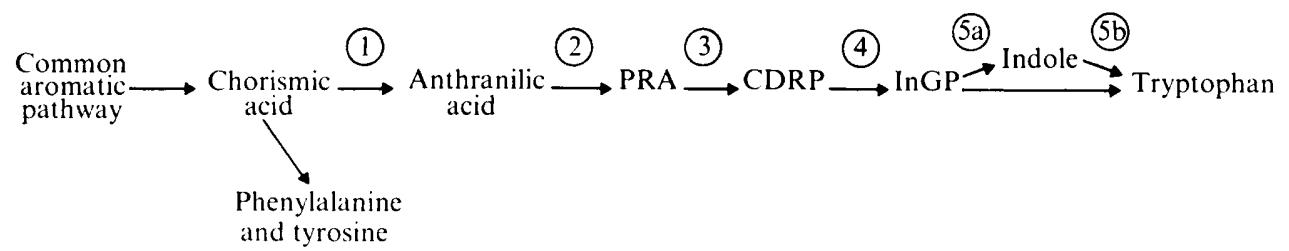

Fig. I. Outline of the tryptophan biosynthetic pathway. PRA, $N$-( $5^{\prime}$-phosphoribosyl)-anthranilic acid; CDRP, I-(o-carboxylphenylamino)-I-deoxyribulose 5-phosphate; InGP, indoleglycerol phosphate. Enzyme activities: I, anthranilate synthetase; 2, phosphoribosyl transferase; 3, PRA isomerase; 4 , InGP synthetase; $5 a+5 b$, tryptophan synthetase.

\section{METHODS}

Strains. The wild-type strains TC4 $A_{2} B_{3}$, JT7 $A_{6} B_{6}$, JTI $5 A_{5} B_{5}$ and JTI $6 A_{6} B_{6}$ were derived from the original stocks isolated from the wild by Professor D. Lewis. The following strains carrying markers representing five of the known linkage groups were used: group I, NGI84 ade-8 $A_{6} B_{6}$ and ZBR 17 met-5 $A_{6} B_{6}$; group III, PR230I met-I $A_{2} B_{3}$; group IV, ZBR23 met-9 $A_{5} B_{5}$; group V, zBR9 met-8 $A_{5} B_{5}$; group $\mathrm{G}$, c692 ade-3, $A_{3} B_{1}$.

Tryptophan mutants. Most mutants were derived from strain TC4 following irradiation of oidia with ultraviolet light. Two mutations, 35 and 36, were induced in JTI5. To satisfy the genetic restrictions on dikaryon formation, the prerequisite for complementation tests and for fruiting, a few of the original mutations were introduced into a new mating type by outcrossing to JT7 or JTI6.

Media. Glucose minimal medium was that used by Lewis (1961) with the addition of $0.25 \mathrm{~g} \mathrm{MgSO}_{4} / 1$ (Casselton \& Casselton, 1966). Filter-sterilized growth supplements were added after autoclaving to give the following concentrations: adenine sulphate, L-methionine, L-tryptophan and anthranilic acid, $0.5 \mathrm{~mm}$, indole, $0.1 \mathrm{~mm}$ (higher indole concentrations are growth inhibitory). Liquid medium contained $10 \mathrm{~g}$ ammonium acetate/ 1 as carbon source in place of glucose, because the latter may react with the anthranilic acid accumulated by mutants (Doy \& Gibson, 1959).

Culture. General techniques for using Coprinus have been described by Lewis (1961) and Anderson (1971). All mycelial cultures were grown at $37^{\circ} \mathrm{C}$. For fruiting a lower temperature $\left(28^{\circ} \mathrm{C}\right)$ and light were required. Cultures grown in liquid medium were initiated from oidia $\left(2.5 \times 10^{5} \mathrm{oidia} / \mathrm{ml}\right.$ final concentration) inoculated into $200 \mathrm{ml}$ of medium in I 1 Erlenmeyer flasks and placed on a rotary shaker (I $40 \mathrm{rev} . / \mathrm{min}$; throw, $12 \mathrm{~mm}$ ).

Accumulation of biosynthetic intermediates. Liquid cultures were grown for 5 days in medium supplemented with tryptophan. The mycelia were collected by centrifugation ( $1000 \mathrm{~g}$ for $15 \mathrm{mins})$, washed with water $(200 \mathrm{ml})$, collected and resuspended in $100 \mathrm{ml}$ of medium without tryptophan. After a further 2 days' incubation the cultures were each shaken with toluene $(0.3 \mathrm{ml})$, left for an hour, and the toluene evaporated. The media were separated from the mycelia by filtration (Whatman No. I). Dry weights of all mycelia were similar.

Identification of intermediates. Anthranilic acid and I-(o-carboxylphenylamino)-Ideoxyribulose 5-phosphate (CDRP) were identified by a procedure based on that of Doy \& Gibson ( 1959 ). Fifty $\mathrm{ml}$ of acidified medium $(\mathrm{pH} 4)$ were extracted with $50 \mathrm{ml}$ ethyl acetate which was then dried over anhydrous $\mathrm{Na}_{2} \mathrm{SO}_{4}$ and reduced under vacuum to $2 \mathrm{ml}$, taking care not to evaporate to dryness. A $0.1 \mathrm{ml}$ portion of the concentrate was subjected to paper chromatography, using the solvent methanol- $n$-butanol-benzene-water $(2: 1: 1:$, , by vol $)$ and 
Whatman No. I paper. Anthranilic acid was identified as a spot, strongly fluorescent under u.v. light, with the same $R_{F}$ as pure anthranilic acid. CDRP should appear as a slowermoving fluorescent spot. Indoleglycerol phosphate (InGP) was assayed in the medium using the ferric chloride reagent and the periodate oxidation methods (Yanofsky, I956). Indoel was tested for with the indole reagent (Yanofsky, I955).

\section{RESULTS}

\section{Complementation analysis}

Thirty-one tryptophan-requiring mutants were studied. Only six of these were recovered in strains with a new, compatible, mating type because of a technical difficulty encountered in the early work. Basidiospores carrying a $t r p^{-}$mutation germinated poorly, making it difficult to recover $t r p^{-}$progeny. However, the few mutants recovered through crosses were sufficient to allow a limited complementation analysis in dikaryons. On this basis the mutants could be separated into four well-defined groups (Table I). Taken together with the genetical data presented below, it was concluded that there are four genes involved and these were designated $\operatorname{trp}-I, \operatorname{trp}-2, \operatorname{tr} p-3$ and $\operatorname{tr} p-4$. Interallelic complementation was detected between the tpr-I mutants, 14 and 7 .

\section{Genetic analysis}

In crosses between $t r p^{+}$and $t r p^{-}$strains, germination of basidiospores on medium supplemented with tryptophan was generally no more than $50 \%$ and most of the progeny carried the $t r p^{+}$allele. The phenomenon was neither allele nor locus specific, and was unaffected by tryptophan concentration. By plating spores at low density it was found that trp- spores germinated very slowly. Once growth was established, $t r p^{-}$colonies grew at similar rates to $t r p^{+}$colonies. This suggests that basidiospores have a poorly developed system for uptake or utilization of exogenous tryptophan. Interestingly, medium supplemented with indole supported normal germination of basidiospores of those $t r p^{-}$mutants which could utilize indole as an alternative growth supplement to tryptophan. Uptake of exogenous indole is therefore independent of tryptophan uptake.

Mutants, representative of the four $t r p^{-}$complementation groups identified, were crossed to strains carrying markers in each of five of the eight known linkage groups of Coprinus lagopus (Moore, 1967; Moore \& Stewart, 197I). Although it was possible to recover all the progeny genotypes in crosses involving those $t r p^{-}$mutants which utilized indole this was not always attempted, and in some crosses only the $t r p^{+}$progeny were analysed (Table 2 ). Two of the loci, $t r p$-I and $t r p-3$, showed close linkage to the met-I locus in linkage group III, while $t r p-2$ was located in linkage group G some 15 units from ade-3. No linkage was detected between $t r p-4$ and either the other three $t r p$ loci or the linkage group markers tested.

To confirm that $\operatorname{trp}-I$ and $\operatorname{tr} p-3$ are not identical and to determine their relative order with respect to met-I, the following three point cross was made:

$$
\operatorname{trp}-\mathrm{I} \text { met }-\mathrm{I}^{+} \operatorname{trp}-3^{+} \times \operatorname{trp}-\mathrm{I}^{+} \text {met-I trp-3. }
$$

Recombinant progeny of genotype $\operatorname{trp}-\mathrm{I}^{+}$met- $\mathrm{I}^{+}$were selected by plating basidiospores from the cross on medium supplemented with anthranilic acid. trp-3 mutants can utilize this supplement and hence the alleles at this locus remain unselected.

Forty-two $\operatorname{trp}-\mathrm{I}^{+} \mathrm{met}_{-\mathrm{I}} \mathrm{I}^{+}$recombinants were recovered from $\mathrm{I} \cdot 7 \times 10^{4}$ viable spores plated, giving an estimated recombination frequency between these two loci of $0.5 \%(0.3 \%$, Table 2). Of these recombinants, 36 were $t r p-3^{+}$and six $t r p-3$. Together with the observed recombination frequency between $m e t-I$ and $t r p-3$ of $6.2 \%$ (Table 2 ), these results indicate 
Table I. Complementation analysis of tryptophan-requiring mutants

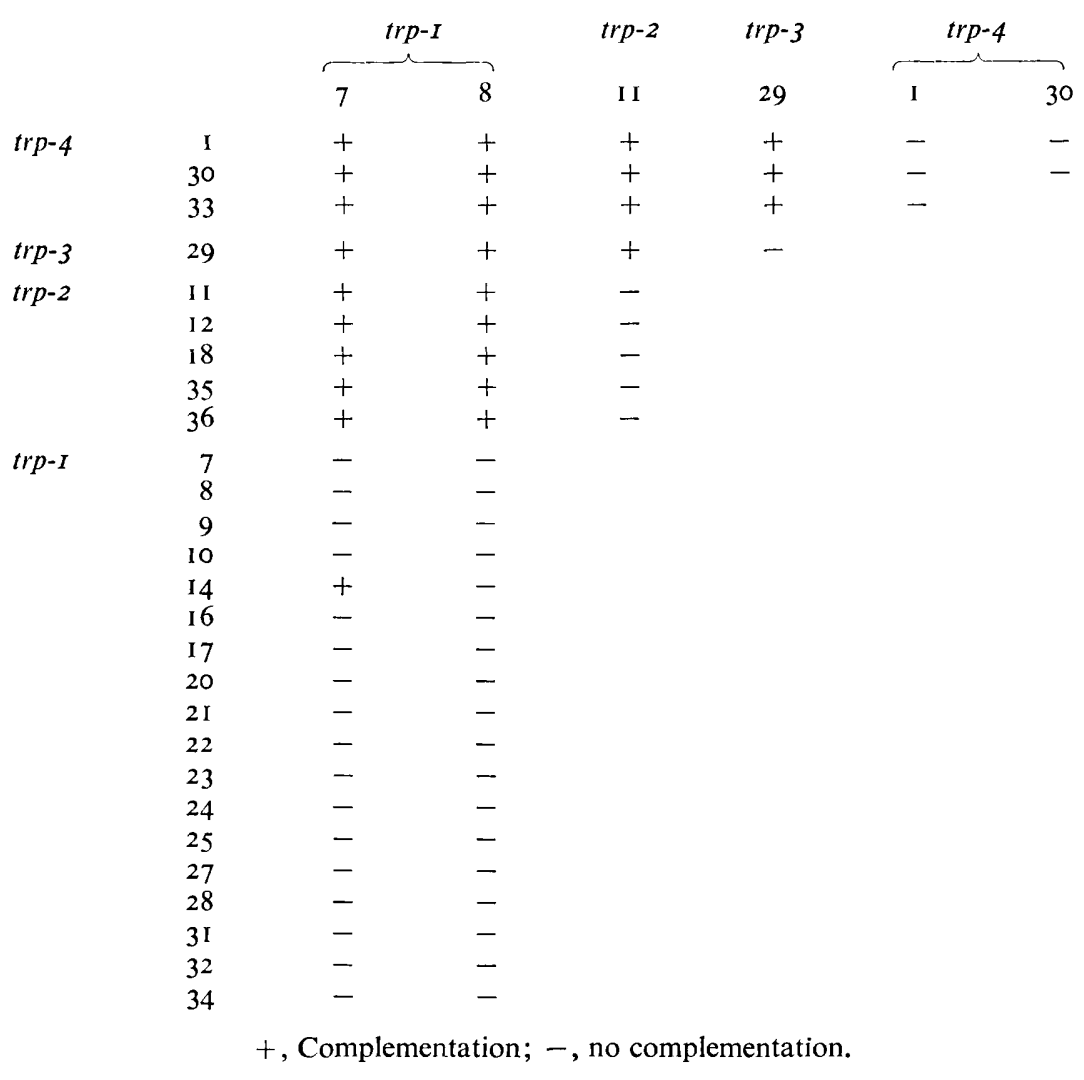

Table 2. Number of progeny of each genotype recovered from two point crosses between mutants of the four trp loci and markers on linkage groups III and $G$

Number of progeny of genotype:

\begin{tabular}{|c|c|c|c|c|c|c|c|}
\hline $\begin{array}{c}\text { Linkage } \\
\text { group }\end{array}$ & Marker & $\begin{array}{c}\text { trp } \\
\text { locus }\end{array}$ & $\begin{array}{l}\text { trp }^{+} \\
\text {met }^{-}\end{array}$ & $\begin{array}{l}\text { trp } \\
\text { met }^{+}\end{array}$ & $\begin{array}{l}\operatorname{trp}^{+} \\
\text {met }^{+}\end{array}$ & $\begin{array}{l}\text { trp } \\
\text { met }\end{array}$ & $\begin{array}{c}\text { Percentage } \\
\text { recombination } \\
\pm \text { S.E. }\end{array}$ \\
\hline \multirow[t]{5}{*}{ III } & met-I & $\operatorname{trp}-\mathrm{I}$ & $\begin{array}{r}777 \\
71\end{array}$ & $\overline{70}^{*}$ & $\begin{array}{l}2 \\
\mathrm{I}\end{array}$ & - $_{0}^{*}$ & $0.3 \pm 0.3$ \\
\hline & & trp-2 & $\begin{array}{l}71 \\
75\end{array}$ & -* & $\begin{array}{l}1 \\
93\end{array}$ & $\ldots *$ & $55^{\dagger}$ \\
\hline & & $t r p-3$ & I 88 & 188 & 15 & 10 & $6.2 \pm 0.9$ \\
\hline & & $\operatorname{trp}-4$ & 22 & 38 & 25 & 26 & $46 \dagger$ \\
\hline & & & $\begin{array}{l}\operatorname{trp}^{+} \\
\text {ade }\end{array}$ & $\begin{array}{l}\text { trp } \\
\text { add }^{+}\end{array}$ & $\begin{array}{l}\operatorname{trp}^{+} \\
\text {ade }^{+}\end{array}$ & $\begin{array}{l}\operatorname{trp}^{-} \\
\text {ade }\end{array}$ & \\
\hline \multirow[t]{2}{*}{ G } & ade-3 & $\operatorname{trp}-2$ & 152 & 153 & 25 & 30 & $15.1 \pm 0.8$ \\
\hline & & $\operatorname{trp}-4$ & 49 & —* & $4 I$ & - * & $45^{\circ} 6^{\dagger}$ \\
\hline
\end{tabular}

* No trp $^{-}$progeny expected because the medium was not supplemented with tryptophan or indole.

$\dagger$ Not significantly different from $50 \%$. 
Table 3. Growth of tryptophan-requiring mutants on minimal medium and supplemented minimal medium

\begin{tabular}{lcccc} 
& \multicolumn{4}{c}{ Growth supplement to minimal medium } \\
Mutants & None & $\begin{array}{c}\text { Anthranilic } \\
\text { acid }\end{array}$ & Indole & Tryptophan \\
Wild type & + & + & + & + \\
$t r p-I$ & - & - & - & + \\
$t r p-2$ & - & - & + & + \\
$t r p-3$ & - & + & + & + \\
$t r p-4$ & - & - & + & +
\end{tabular}

+ , Normal growth; -, no growth. Growth was scored after $48 \mathrm{~h}$ incubation.

Table 4. Accumulation of biosynthetic intermediates by tryptophan-requiring mutants

Established mycelia were incubated for 2 days in medium without tryptophan, treated with toluene, the mycelium filtered off and the medium tested for tryptophan biosynthetic intermediates as described under Methods. The amount of anthranilic acid was estimated from the size and intensity of fluorescence of chromatographic spots.

\begin{tabular}{|c|c|c|c|}
\hline Locus & Strain & $\begin{array}{l}\text { Anthranilic* } \\
\text { acid }\end{array}$ & $\begin{array}{l}\text { Indoleglycerol }+ \\
\text { phosphate }\end{array}$ \\
\hline Wild type & TC4 & + & - \\
\hline $\operatorname{trp}-I$ & $\begin{array}{r}7 \\
8 \\
14\end{array}$ & $\begin{array}{l}+++ \\
+++ \\
+++\end{array}$ & $\begin{array}{l}+ \\
+ \\
+\end{array}$ \\
\hline$t r p-2$ & $\begin{array}{l}\text { II } \\
\text { I } 2\end{array}$ & $\begin{array}{c}+ \\
++\end{array}$ & $\begin{array}{l}- \\
-\end{array}$ \\
\hline $\operatorname{trp}-3$ & 29 & + & - \\
\hline $\operatorname{trp}-4$ & 30 & +++ & - \\
\hline
\end{tabular}

the order of these three loci as: trp-I met-I trp-3. Thus it is confirmed that $\operatorname{trp}-I$ and $\operatorname{trp}-3$ are not identical.

\section{Auxanographic tests}

All mutants were tested for ability to utilize anthranilic acid or indole as alternative growth supplements to tryptophan. With one exception, mutants assigned to each locus gave the growth responses recorded in Table 3. The exception was a trp-I mutant (I4) which utilized indole as well as tryptophan. These results allow the following conclusions: (i) trp-I mutants are blocked in the final steps of the pathway which, in other organisms, are catalysed by tryptophan synthetase (reactions $5 \mathrm{a}$ and 5 b, Fig. I); (ii) trp-2 and trp-4 mutants are blocked in the reactions between anthranilic acid and indole (reactions 2, 3,4 or 5a, Fig. I); and (iii) the trp-3 mutant is blocked before anthranilic acid in the reaction which, in other organisms, is catalysed by anthranilate synthetase (reaction I, Fig. I).

\section{Accumulation of intermediates}

Representative mutants were tested for the accumulation of tryptophan biosynthetic intermediates (Table 4). All tests for CDRP and indole were negative. The results support the conclusions drawn from the auxanographic tests and allow the additional conclusion that trp-2 mutants are also blocked, at least partially, in anthranilic acid formation. A block 
only in the conversion of anthranilic acid to indole, as indicated by auxanographic data, would cause strong accumulation of any anthranilic acid produced, but such accumulation was barely detectable. The small amounts of anthranilic acid produced by the $\operatorname{tr} p-3, \operatorname{tr} p-2$ and wild-type strains (Table 4) probably resulted from tryptophan catabolism. This occurs in N. crassa (Matchett \& DeMoss, 1963) and probably also in C. radiatus (Guerdoux, 1967).

\section{DISCUSSION}

Analysis of $3 \mathrm{r}$ tryptophan-requiring mutants has shown that at least four different genes (trp-I, trp-2, trp-3 and trp-4) are necessary for tryptophan biosynthesis in C. lagopus. All the enzyme activities of tryptophan biosynthesis (Fig. I) except tryptophan synthetase have been detected in C. lagopus (Hutter \& DeMoss, 1967). The enzymes controlled by each genetic locus are inferred in the present study from auxanographic tests and accumulated intermediates.

The $\operatorname{trp}-3$ locus is assumed to control anthranilate synthetase since the $\operatorname{trp}-3$ mutant was blocked in anthranilic acid formation. Further support for this comes from the observation that the accumulation of anthranilic acid caused by the trp-4 mutation is prevented in the double mutant trp-3 trp-4. The trp-3 mutant showed no requirement for phenylalanine or tyrosine, which are also synthesised from chorismic acid (Fig. I). In all organisms studied, anthranilate synthetase is the only enzyme preceding anthranilic acid and specific to tryptophan biosynthesis.

Similar evidence indicates that the trp-2 locus also controls anthranilate sythetase. In addition, it controls an activity necessary for the conversion of anthranilic acid to indole. Hutter \& DeMoss ( I 967) presented evidence for an enzyme aggregate in C. lagopus which carries anthranilate synthetase, $\mathrm{N}$-(5'-phosphoribosyl)-anthranilic acid (PRA) isomerase and InGP synthetase activities (reactions I, 3 and 4, Fig. I) similar to a well characterized aggregate in $N$. crassa. It is probable that the trp-2 locus of $C$. lagopus is similar to the locus in $N$. crassa that codes for a polypeptide which carries PRA isomerase and InGP synthetase activities, and which must aggregate with the product of a second locus to form normal anthranilate synthetase activity (Arroyo-Begovich \& DeMoss, 1973), the equivalent of the latter locus in $C$. lagopus being trp-3. In C. radiatus, anthranilate synthetase activity appears to be less dependent on the integrity of the whole aggregate (Henke et al., 1973).

The trp-4 locus is necessary for the conversion of anthranilic acid to InGP and may well control phosphoribosyl transferase, which was not detectably aggregated with other enzymes of the pathway in $C$. lagopus and $N$. crassa (Hutter \& DeMoss, 1967). The very strong accumulation of anthranilic acid by the trp- 4 mutant is consistent with this.

The trp-I locus controls tryptophan synthetase because all but one of the $\operatorname{trp}-I$ mutants were blocked in the last reaction of the pathway ( $5 \mathrm{~b})$. The accumulation of InGP and not indole by the $\operatorname{trp}-I$ strains tested indicates that they were also blocked in reaction 5 a, also catalysed by tryptophan synthetase. The one trp-I mutant (I4) which could utilize indole appears blocked in only reaction 5a. Mutants of this type have been described in N. crassa (Ahmad, Choudhury \& Islam, I969) and Saccharomyces cerevisiae (Manney et al., 1969). It appears that, as in the above fungi, both tryptophan synthetase activites in C. lagopus are coded in the same genetic region.

I thank Dr L. A. Casselton for her help and the Science Research Council for a main tenance grant. 


\section{REFERENCES}

Ahmad, M., Choudhury, MD. K. U. \& Islam, S. M. (1969). Complementation and recombination between indole utilising tryptophan-3 mutants of Neurospora crassa. Heredity 24, 656-660.

Anderson, G. E. (1971). The Life History and Genetics of Coprinus lagopus. Weston-super-Mare, Somerset: Harris Biological Supplies Ltd.

Arryo-Begovich, A. \& DeMoss, J. A. (1973). The isolation of the components of the anthranilate synthetase complex from Neurospora crassa. Journal of Biological Chemistry 248, 1262-1267.

Bonner, D. M., DeMoss, J. A. \& Mills, S. E. (1965). The evolution of an enzyme. In Evolving Genes and Proteins, pp. 305-3 I 8. Edited by V. Bryson and H. J. Vogel. New Ycrk and London: Academic Press.

Casselton, L. A. \& Casselton, P. J. (1966). Control of fruiting of Coprinus lagopus on certain synthetic media. Transactions of the British Mycological Sociey 49, 579-58I.

Crawford, I. P. (1975). Gene rearrangements in the evolution of the tryptophan synthetic pathway. Bacteriological Reviews 39, 87-120.

DeMoss, J. A., Jackson, R. W. \& Chalmers, J. H. (1967). Genetic control of the structure and activity of an enzyme aggregate in the tryptophan pathway of Neurospora crassa. Genetics 56, 4I 3-424.

Doy, C. H. \& Gibson, F. (I959). I-(o-Carboxylphenylamino)-I-deoxyribulose. A compound formed by mutant strains of Aerobacter aerogenes and Escherichia coli blocked in the biosynthesis of tryptophan. Biochemical Journal 72, 586-597.

Guerdoux, J.-L. (1967). Induction de la cynuréninase par la cynurénine, les tryptophane et 5-méthyltryptophane chez le Coprinus radiatus. Comptes rendus hebdomadiare des séances de l'Académie des sciences D 265, 68 I-684.

Henke, H., Guerdoux, J.-L. \& Hutter, R. (I973). Relations entre les gènes et les enzymes de la biosynthèse du tryptophane chez le Coprinus radiatus. Comptes rendus hebdomadaire des séances de l'Académie des sciences $\mathbf{D}$ 276, $2001-2004$.

Hutter, R. \& DeMoss, J. A. (1967). Organisation of the tryptophan pathway: a phylogenetic study of the fungi. Journal of Bacteriology 94, $1896-1907$.

LEwIS, D. (196I). Genetical analysis of methionine suppressors in Coprinus. Genetical Research 2, 14 I-I 55.

Manney, T. R., Duntze, W., Janosko, N. \& Salazar, J. (1969). Genetic and biochemical studies of partially active tryptophan synthetase mutants of Saccharomyces cerevisiae. Journal of Bacteriology 99, 590-596.

MatchetT, W. H. \& DeMoss, J. A. (1963). Direct evidence for a tryptophan-anthranilic acid cycle in Neurospora. Biochimica et biophysica acta 7r, 632-642.

Moore, D. (1967). Four new linkage groups in Coprinus lagopus. Genetical Research 9, 33 I-342.

Moore, D. \& STEWART, G. R. (197I). Mutants of Coprinus lagopus selected for resistance to 2-deoxy-Dglucose. Genetical Research 18, 34I-352.

RoBerts, C. F. (1967). Complementation analysis of the tryptophan pathway in Aspergillus nidulans. Genetics 55, 233-239.

YANOFSKY, C. (1955). Tryptophan synthetase from Neurospora. In Methods in Enzymology, vol. 2, pp. 233238. Edited by S. P. Colowick and N. O. Kaplan. New York and London: Academic Press.

YANOFSKY, C. (1956). The enzymatic conversion of anthranilic acid to indole. Journal of Biological Chemistry 223, I 7 I-I 84 . 